\title{
New fossil record of Lactoridaceae in the Paleogene of southern Patagonia (South America)
}

\author{
Mirta Elena QUATTROCCHIO
}

\begin{abstract}
Instituto Geológico del Sur-Consejo Nacional de Investigaciones Científicas y Técnicas Departamento de Geología, Universidad Nacional del Sur, San Juan 670, B8000ICN Bahía Blanca, Buenos Aires, Argentina. mquattro@criba.edu.ar
\end{abstract}

\begin{abstract}
The new record of the family Lactoridaceae (Rosannia manika Srivastava) in Tierra del Fuego, Austral Basin corresponds to a sedimentary succession located at the south of the Irigoyen River, nearby the Cerro Malvinera. The palynology (principally dinoflagellates cysts) of different Paleogene formations (La Barca, Punta Torcida and Puesto José) in the Austral Basin was analyzed to calibrate the age of this outcrop. This result was compared with large datasets of organic dinoflagellate cyst (dinocyst) assemblages from Southern Pacific Ocean shelf sediments and other sections of the world. The majority of the palynomorph taxa from the Cerro Malvinera succession are present in the upper member LB2 of the La Barca Formation and both shared the presence of Lactoridaceae (Rosannia manika Srivastava) and the age-diagnostic dinocysts Pentadinium laticinctum (First Occurrences 51.95 Ma). An age not older than early Eocene is proposed for the LB2 member of the La Barca Formation and the Cerro Malvinera strata. This data expands the known fossil range of the Lactoridaceae in Patagonia and contributes to elucidate the probably migration routes of this family. A migration via Antarctica is postulated in this paper due to the record of this family in the Maastrichtian (López de Bertodano Formation). Depending on new records, due to the presence of this family in the Colorado Basin in the Danian, a migration route from the north of Patagonia to the south (Austral Basin) it is not discarded.
\end{abstract}

Key words: Lactoridaceae, Paleogene, southern Patagonia, South America.

Resúmen: Nuevo registro fósil de Lactoridaceae en el Paleógeno de Patagonia austral (América del Sur). Se presenta un nuevo registro de la familia Lactoridaceae (Rosannia manika Srivastava) correspondiente a una sucesión sedimentaria localizada al sur del río Irigoyen, cercano al Cerro Malvinera, Tierra del Fuego, cuenca Austral. Para calibrar la edad del afloramiento se analizó la palinología (principalmente quistes de dinoflagelados) de diferentes formaciones paleógenas (La Barca, Punta Torcida y Puesto José) de la cuenca Austral. Este resultado fue comparado con bases de datos de quistes de dinoflagelados (dinoquistes) correspondientes a sedimentos de plataforma del Océano Pacífico Sur y de otras secciones del mundo. La mayoría de los taxones de palinomorfos de la sucesión de Cerro Malvinera están presentes en el miembro superior LB2 de la Formación La Barca y ambos comparten la presencia de Lactoridaceae (Rosannia manika Srivastava) y dinoquistes diagnósticos de edad como Pentadinium laticinctum (First Occurrences 51.95 Ma). Se propone una edad no más antigua que Eoceno temprano para el miembro LB2 de la Formación La Barca y los estratos analizados de Cerro Malvinera. Este dato amplia el rango fósil y contribuye a elucidar las rutas de migración probable de la familia Lactoridaceae en Patagonia. La migración vía Antártida es postulada en éste trabajo debido al registro de la familia en el Maestrichtiano (Formación López de Bertodano) Dependiendo de nuevos registros, no se descarta una ruta de migración desde el norte de Patagonia al sur (Cuenca Austral) debido a la presencia de la familia en el Daniano de la Cuenca del Colorado.

Palabras clave: Lactoridaceae, Paleógeno, Sur de Patagonia, America del Sur.

\section{INTRODUCTION}

In this paper we report a new fossil finding of Lactoridaceae tetrads form the Paleogene of southern Patagonia (Austral Basin), southern South America. Lactoridaceae are a monotypic family of shrubby angiosperms represented by a lone species: Lactoris fernandeziana Phil., now endemic to the cloud forests of Masatierra Island (= Robinson Crusoe) located at an altitude of $500 \mathrm{~m}$ and above (Crawford et al., 1991, 1994; Stuessy et al., 1997, 1998). The island belongs to the Juan Fernandez Group, located $667 \mathrm{~km}$ off the west coast of Chile in the Pacific Ocean. 
This species possesses both primitive and highly specialised/reduced characters (Carlquist, 1964). The Lactoridaceae are considerer to form part of an early-branching of angiosperms pertaining to the "paleoherbs" (according to Donoghue \& Doyle, 1989), and to understanding of the early angiosperm evolution. It has being assigned to the Order Piperales based on exine structure and wood anatomy, the LauraIes, and the Magnoliales based on cladistic, and chemotaxonomic studies (from Macphail et al., 1997 and bibliography cited in this paper). Endress (1994) has summarized features of Lactoris which he considers implies a relationship with the Aristolochiales (Aristolochia). This is supported by phylogenetic analysis based on nucleotide sequences in the plastid gene rbcL (Chase et al., 1993).

Little is known of its reproductive biology. Lactoris is anemophilous, a syndrome perhaps reflected by the $\mathrm{P} / \mathrm{O}$ (pollen/ovule) ratio. Low genetic diversity (isozymes and DNA) supports selfing and implies limited distance wind pollen dispersal. If the primitive angiosperms to which Lactoridaceae is related (Piperales, Magnoliales, Aristolochiales, Laurales; Stuessy et al., 1998) are presumed to be insect pollinated the anemophily is derived (Bernardello et al., 1999).

The discovery of fossil pollen of Lactoridaceae in the Upper Cretaceous (lower TuronianCampanian) of the south-west coast (Orange Basin offshore Namaqualand), South Africa suggests that this family may have been a common element in the Cretaceous Gondwana flora (Zavada \& Benson, 1987). The Turonian age for the Lactoridaceae should be cautiously accepted since the type material come from cutting samples (Srivastava \& Braman, 2010).

The new register of the family in the area

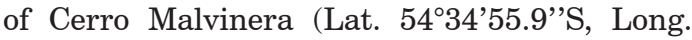
$66^{\circ} 37^{\prime} 22.8^{\prime \prime} \mathrm{W}$, Austral Basin) corresponds to a sample in a succession of c. $180 \mathrm{~m}$ of black mudstones with minor intercalated sandstone beds, which was correlated to the Paleogene La Barca Formation (Torres Carbonell et al., 2008). The outcrops are located to the south of Irigoyen River where the mudstone-dominated succession is adjacent to Upper Cretaceous strata of the Policarpo Formation, but the stratigraphic contacts cannot be observed.

To evaluate the age of the succession at Cerro Malvinera its palynology (principally dinoflagellates cysts) was compared to that of different Paleogene formations (La Barca, Punta Torcida and Puesto José) at its type locality, exposed in the Austral Basin. The results were compared with large datasets of organic dinoflagellate cyst (dinocyst) assemblages from Southern Ocean shelf sediments and from other sections in the World ( Bijl et al., 2013, William et al., 1998, 1999, 2003).

It was also compared with a high-resolution Southern Pacific Ocean dinocyst zonation for the late Palaeocene to late Eocene (58-36 million years ago; $\mathrm{Ma}$ ). The zonation consists of thirteen dinocyst zones, calibrated to the Geomagnetic Polarity Time Scale (GPTS) of Vandenberghe et al. (2012), which can likely be applied, to the entire Southern Ocean (Bijl et al., 2013).

The present results expanded the known fossil record of the Lactoridaceae in Patagonia and it is a contribution to elucidate the probably migration routes of this family.

\section{STUDIED LOCALITY AND COMPARED PALEOGENE FORMATIONS}

The mountain front of the Fuegian Andes is formed by the Fuegian Thrust-Fold Belt, which constitutes a thin-skinned wedge that involves Upper Cretaceous to Miocene sequences (Klepeis \& Austin, 1997; Ghiglione et al., 2002; Torres Carbonell et al., 2008). The stratigraphic successions involved in the thrust-fold belt correspond to the Magallanes/Austral foreland basin, and the successions have been divided into several unconformity bounded sequences (Olivero \& Malumián, 2008) that records the kinematic evolution of the Fuegian Thrust-Fold Belt. During the Paleogene, the foreland successions cropping out at the Atlantic shore include two main tectonically controlled depocenters: a foredeep depocenter with early Eocene deep marine turbidites of the Punta Torcida Formation, and a wedge-top depocenter filled with several Eocene to Oligocene formations (Torres Carbonell et al., 2009; Torres Carbonell \& Olivero, 2011), of which the mudstones of the Puesto José Formation are of interest for this study. The interpretation of the La Barca Formation is presently not clear, and it was tentatively considered either as part of relatively shallow fandeltaic systems flanking the northern mountain front or as part of a Paleogene-Eocene foredeep system (Olivero et al., 2002; Torres Carbonell et al., 2009).

The record of the Lactoridaceae family correspond to the Cerro Malvinera locality (54 $34^{\circ} 55.9^{\prime \prime} \mathrm{S} ; 66^{\circ} 37^{\prime} 14.4^{\prime \prime} \mathrm{W}$ ) (Fig. 1). In artificial cuts, south of the Irigoyen River the sedimentary sequence of aproximatly $180 \mathrm{~m}$ cor- 


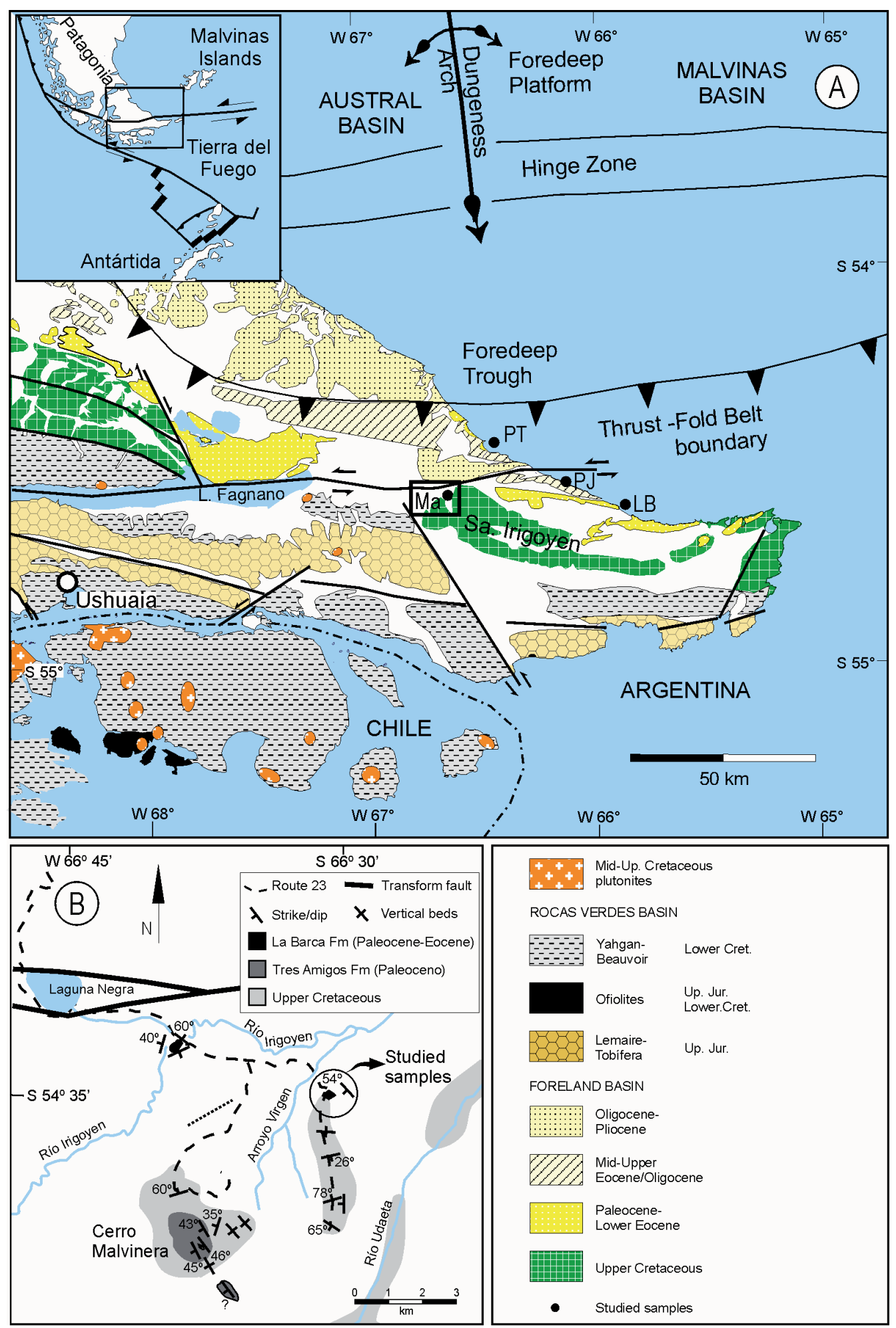

Fig. 1. A. Geological map of Tierra del Fuego province showing sample collection localities. Ma: Cerro Malvineras. LB: La Barca. PJ: Puesto José. PT: Punta Torcida (compiled from Olivero \& Malumian, 2008 and Torres Carbonell et al., 2009). B: Location map of Cerro Malvinera. 
respond to pelites with thin interbedded sandstones. The studied samples correspond to the Upper Cretaceous Policarpo Formation and the Paleogene succession. The Cretaceous samples include: samples 684; 685; 686-1, and 686-2 (with Spiroplectammina spectabilis: MaastrichtianEocene, com. pers., N. Malumián). The Paleogene samples, includes (from top to bottom): samples 687; 687-1; 687-2; 687-3 (with Rhabdamina); 687-4; 688 (with Lactoridaceae). Only one out of ten samples was palynologically fertile (sample $688)$.

\section{La Barca Formation (Olivero et al., 2002)}

The La Barca Formation, only recognized at the type locality (Fig.1), c. 220 m, includes a lower member LB1, of tuffaceous sandstones and intercalated carbonaceous siltstones; and an upper member LB2 of black mudstones (Olivero \& Malumián, 2008). In the La Barca Formation a restricted horizon of the lower member LB1 $(100 \mathrm{~m})$ bears a mostly cosmopolitan Midway Type assemblage dominated by buliminids; the assemblage includes the dominant Bulimina karpatica, and exceptional endemic species such as Buliminella isabelleana and Antarcticella sp., both known from Antarctica and very common and widespread in Patagonia. LB2 (120 m) contains only scarce agglutinated foraminifera, dominated by Spiroplectammina spectabilis (Malumián \& Caramés, 2002; Olivero \& Malumián, 2008).

There has not been register diagnostic megafauna in the La Barca Formation. The associations of dinocysts (Palaeocystodinium golzowense and Glaphyrocysta sp.) of the member LB1 are poor preserved. In LB2 member only Palaeocystodinium golzowense was recognized (Olivero et al., 2002). A Late Paleocene age was proposed for LB2 member (Olivero et al., 2002).

The studied samples in this paper correspond to LB2 member: $80 \mathrm{~m}$ (372-19) and $180 \mathrm{~m}$ (37225) above the sample with Paleocene forams of the LB1 member.

\section{Punta Torcida Formation (Olivero \& Malumián, 1999)}

The type section of the Punta Torcida Formation, including the members PTa, PTb, $\mathrm{PTc}$, and unnamed strata, is exposed at the eponymous area (Olivero \& Malumián, 1999; Jannou \& Olivero, 2001). The lower PTa member (> 74 $\mathrm{m}$ ) is composed of dark gray mudstones with thin sandstone beds; the PTb member $(58 \mathrm{~m})$, mudstones with small sandstone lenses, both mem- bers include levels with high radiolarian content; and the PTc member $(83 \mathrm{~m})$ mudstones (Olivero $\&$ Malumián, 1999). The upper unnamed strata (ca. $200 \mathrm{~m}$ ) consist of turbidites and tuffaceous mudstones (Olivero \& López, 2001; Olivero et al., 2002, 2004).

The formation contains abundant ostracods (Jannou, 2009) foraminifera and radiolarians. Most of the benthic foraminifera were described from the Agua Fresca Formation in the pioneer work in Austral Basin of Todd \& Kniker (1952) and include common endemic species such as Antarcticella ceccioni. Planktonic foraminifera indicate an early Eocene age and the benthonic ones are mostly dominated by agglutinated forms typical of turbiditic settings (Olivero \& Malumián, 1999). The radiolarians are correlated with the RP 10 Zone of the South Pacific calibrated between 51 to $47 \mathrm{Ma}$ (Hollis, 1997) by Jannou (2014).

\section{Puesto José Formation (Torres Carbonell et al., 2009)}

The Puesto José Formation is a very thick (e. $1600 \mathrm{~m}$ ), monotonous mudstone-dominated succession (Torres Carbonell et al., 2009) exposed on the Atlantic shore in the Cape José area (Fig. 1) between Puesto José (54 $\left.34^{\circ} \mathrm{S} ; 66^{\circ} 06^{\prime} \mathrm{W}\right)$ and Puesto La Chaira (54 $33^{\prime} \mathrm{S}$; $\left.66^{\circ} 09^{\prime} \mathrm{W}\right)$. The lower section $(370 \mathrm{~m})$ is composed of grey massive pelite, the middle section $(655 \mathrm{~m})$ of mudstones with fine sandstone lenses and the upper $(575 \mathrm{~m})$ of grey mudstones with fine to medium sandstone intercalations.

Based on the foraminifer content, this Formation is equivalent with the Oligocene "capas" de la Estancia María Cristina and Puesto Herminita (Scarpa \& Malumián, 2008), and with the 'Glauconítico A' and 'Margosa Superior' in the subsurface of the Austral Basin (cf. Malumián \& Olivero, 2006; Malumián et al., 2008).

In the type section the last occurrence datum of $S$. angiporoides restrict the age of the strata below this level to the early Oligocene (30 Ma) Torres Carbonell et al., 2009.

\section{MATERIAL AND METHODS}

The palynomorphs were recovered from outcrop samples corresponding to different Paleogene formations of the Austral Basin (Table 1). Age control was provided principally by foraminifera, dinoflagellates and spore and pollen species whose time distributions are significant.

Due to the characteristics of the analyzed for- 
Table 1: Studied samples, Paleogene of Austral Basin.

\begin{tabular}{|c|c|c|c|c|}
\hline Formation/locality & Co. Malvinera & La Barca (LB2 member) & Punta Torcida & Puesto José \\
\hline Outcrop samples/ & $688(3121)$ & $372-25(4045)$ & $506(4047)$ & $133(4049)$. \\
(Palynological samples) & & $372-19(4046)$ & $50 B(4048)$ & POI120-1 (4050) \\
\hline
\end{tabular}

mations, with common reworked material during different phases of the episodic evolution of the thrust-fold belt only the palynomorphs in a good state of preservation were considered.

The material physically or chemically altered was considered reworked from older deposits.

Physical and chemical extraction was carried out using standard palynological processing techniques (Volkheimer \& Melendi, 1976), which involve treatment with hydrochloric and hydrofluoric acids. A brief oxidation (two minutes or less) in nitric acid was realized. The residue was sieved through a $10 \mu \mathrm{m}$ mesh to concentrate the palynomorphs. All figured specimens are lodged in the collections of the Palynological Laboratory, Universidad Nacional del Sur, Bahía Blanca, Argentina. In the citation of specimens referred to or illustrated, the sample and slide number is given first and the position on the slide indicated by an England Finder reference (e.g. G36/4).

\section{List of identified palynomorphs}

\section{Spores}

Baculatisporites comaumensis (Cookson) Potonié 1956

Biretisporites crassilabratus Archangelsky 1972 (Fig. 3J)

Cingutriletes australis (Cookson) Archangelsky 1972

Corrugatisporites argentinus Archangelsky 1972

Cyathidites paleospora (Martin) Alley \& Broadbridge 1992 (Fig. 3K)

Cingutriletes australis (Cookson) Archangelsky 1972 (Fig. 3L)

\section{Gymnosperm pollen}

Araucariacites australis Cookson 1947

Dilwynites granulatus Harris 1965

Microcachryidites antarcticus (Cookson) Couper 1953

Phyllocladidites mawsonii (Cookson) Couper 1953 (Fig. 4B)

Podocarpidites spp.

\section{Angiosperm pollen}

Diporites aspis Pocknall \& Mildenhall 1984

Nothofagidites fortispinulosus Menéndez \& Caccavari de Filice 1975 (Fig. 4A)
Nothofagidites spp.

Proteacidites sp. (in Fasola 1969) (Fig. 4C)

Rosannia manika Srivastava emend. Srivastava \& Braman 2010 (Fig. 4D)

Rosannia cf. $R$. manika (Fig. 4E-F)

\section{Dinoflagellates}

Achilleodinium latispinosum (Davey \& Williams 1966) Bujak et al., 1980 (Fig. 2A)

cf. Adnatosphaeridium sp. A (in Bijl et al., 2013) (Fig. 2B)

Apectodinium homomorphum (Deflandre \& Cookson) Lentin (Fig. 2C)

\& Williams, 1977 emend. Harland, 1979

Batiacasphaera rifensis Slimani et al., 2008 (Fig. 2D)

Batiacasphaera micropapillata Stover 1977 (Fig. 2E)

Cleistosphaeridium diversispinosum Davey et al . 1966 emend. Eaton et

al., 2001 (Fig. 2F)

Deflandrea fuegiensis Menéndez 1965 (Fig. 2G)

Dracodinium waipawaense (Wilson) Costa \& Downie 1979 (Fig. 2H)

Habibacysta sp.

Hystrichosphaeridium tubiferum (Ehrenberg) Deflandre 1937 emend. Davey \& Williams 1966 (Fig. 2I)

Impagidinium maculatum (Cookson \& Eisenack) Stover \& Evitt 1978 (Fig. 2J)

Isabelidinium bakeri (Deflandre \& Cookson) Lentin \& Williams 1977 (Fig. 2K)

Lejeunecysta fallax (Morgenroth 1966) Artzner \& Dörhöfer 1978 (Fig. 2L)

Lejeunecysta cf. pulcra Biffi \& Grignani 1983

Lingulodinium bergmannii (Archangelsky) Quattrocchio \& Sarjeant 2003(Fig. 2M)

Magallanesium sp. (Fig. 2N)

Membranisphoridium perforatum Wilson 1988 (Fig. 2Ñ, Fig. 3A)

Oligosphaeridium complex (White) Davey \& Williams 1966 (Fig. 3B)

Operculodinium azcaratei Troncoso \& Doubinger 1980 (Fig. 3C)

Palaeocystodinium golzowense Alberti 1961 (Fig. 3D)

Pentadinium laticinctum Gerlach 1961 emend. Benedek et al., 1982 (Fig. 3E)

Phthanoperidinium coreoides (Benedek) Lentin 


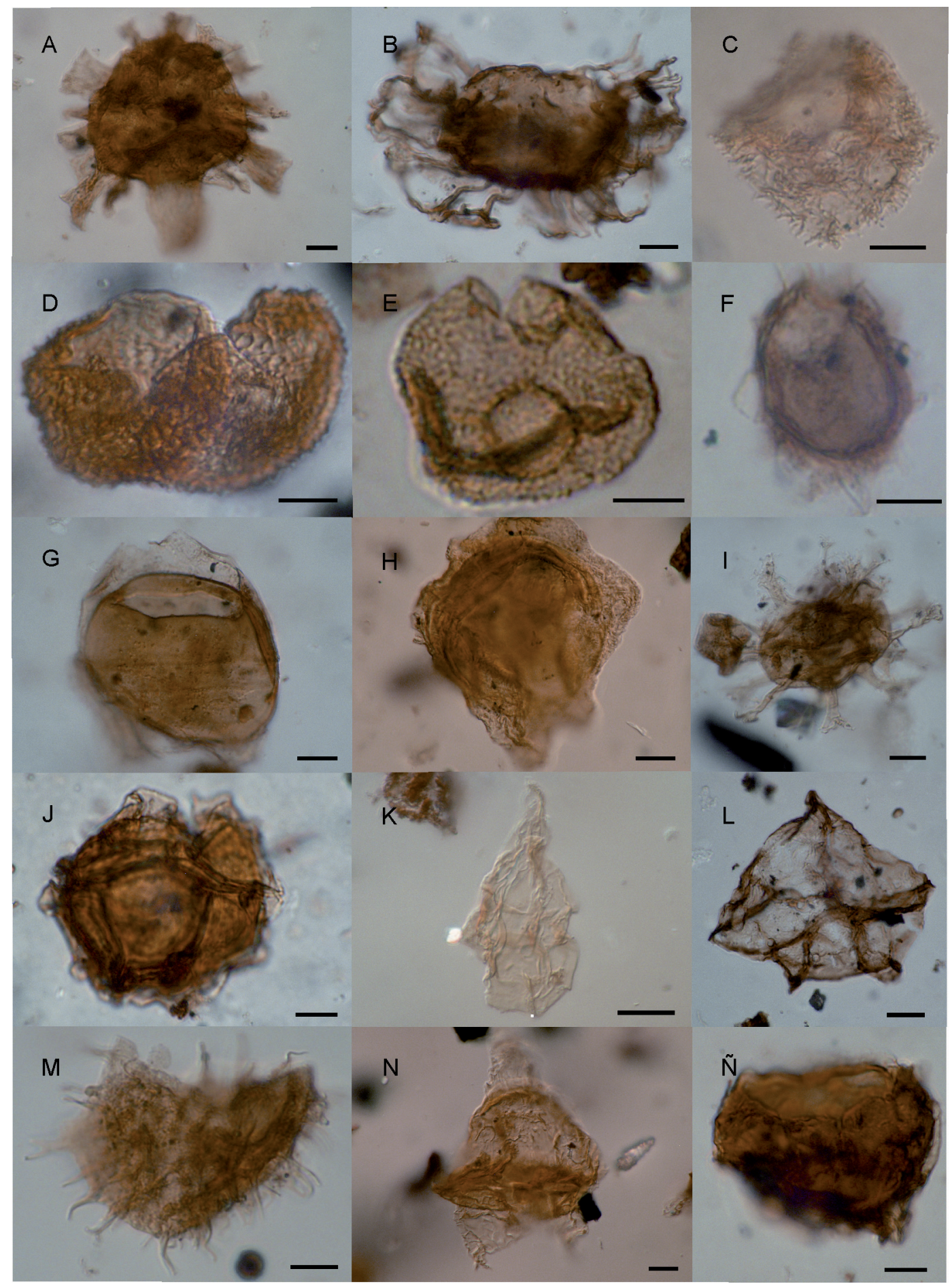

Fig. 2. A. Achilleodinium latispinosum: 4048c:C65/2. B. cf. Adnatosphaeridium sp. A: 4047c:D43/3. C Apectodinium homomorphum: 4048a:D49. D. Batiacasphaera rifensis: 4046a:R39. E. Batiacasphaera micropapillata: 4045c: H34/3. F. Cleistosphaeridium diversispinosum: 4048c:F60/4. G. Deflandrea fuegiensis: 4048a:N39. H. Dracodinium waipawaense: 4047c: K61/3. I. Hystrichosphaeridium tubiferum: 4048c: E36. J. Impagidinium maculatum: 4048a: Q69/2. K. Isabelidinium bakeri: 4046a: E37/3. L. Lejeunecysta fallax: 4049a: K62/2. M. Lingulodinium bergmannii: 4048c:F60/1.N.Magallanesium sp.:4046a:G33.N. Membranisphoridiumperforatum:4048c:G67/2. Scalebars=10 $\mu \mathrm{m}$. 


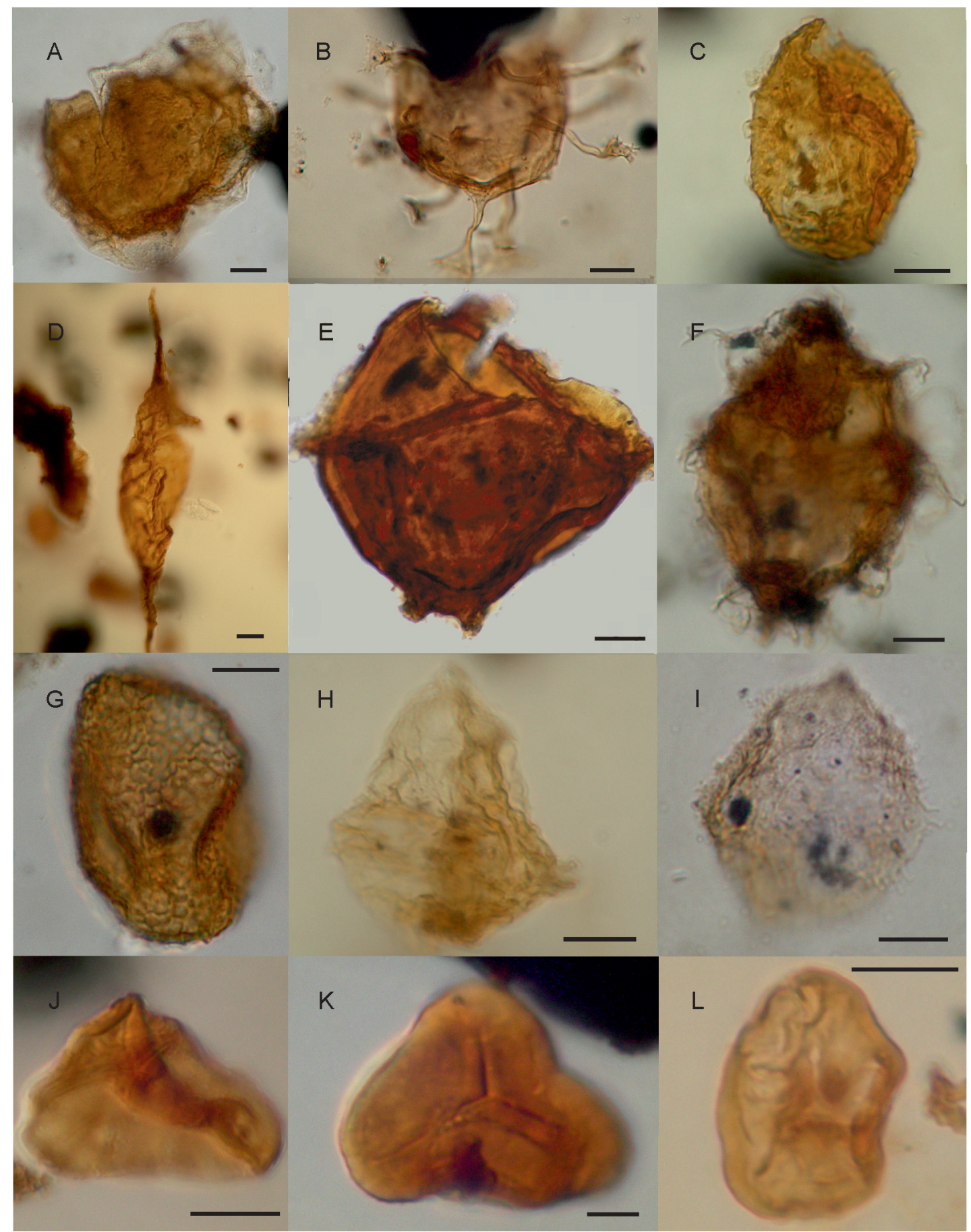

Fig. 3. A. Membranisphoridium perforatum: 4047c: E60. B. Oligosphaeridium complex: 4048c: V69/3. C. Operculodinium azcaratei: 4046a: U50. D. Palaeocystodinium golzowense: 4046a: M36/3. E. Pentadinium laticinctum: 3121/2: T33. F. Phthanoperidinium coreoides: 4049a: K62/2. G. Pyxidinopsis waipawaensi: $4048 \mathrm{a}:$ M33. H.Volkheimeridium lanterna:4046b: P44.I. Vozzhennikovia apertura: 4048a: U58/4. J. Biretisporites crassilabratus: 4046a: G35. K. Cyathidites paleospora: 4046a: P48. L. Cingutriletes australis: 4045a: P50/3. Scale bars $=10 \mu \mathrm{m}$. 
\& Williams 1976 emend. Benedek \& Sarjeant 1981 (Fig. 3F)

Pyxidinopsis waipawaensi Wilson 1988 (Fig. $3 \mathrm{G})$

Spiniferites ramosus (Ehrenberg) Mantell 1854

Volkheimeridium lanterna (Cookson \& Eisenack)

Quattrocchio \& Sarjeant 2003(Fig. 3H)

Vozzhennikovia apertura (Wilson 1967) Lentin

\& Williams 1976 (Fig. 3I)

\section{Acritarchs}

Pterospermella sp.

\section{SYSTEMATIC DESCRIPTION}

The original diagnosis of the genus Rosannia as $R$. manika, were based on a misinterpretation of its morphological characteristics (Srivastava, 1968). The genus was erroneuously diagnosed as a monad. Rosannia would have priority over Lactoripollenites Zavada \& Benson, 1987.

Gamerro \& Barreda (2008) found fossil tetrads of Lactoridaceae and informally named as 'Lactoris type' pending an emended diagnosis of Rosannia based on the type material. It was done in Srivastava \& Braman (2010). Then this material is assigned here to the genus Rosannia.

\section{Rosannia manika (Srivastava) Srivastava \& Braman 2010}

Description: Pollen grains shed in permanent tetrads, radiosymmetric. Individual grains monoporate, ana-ulcerate, slightly constricted proximally but distally flared; pore large situated at the distal end of an individual grain (diameter: $9 \mu \mathrm{m}$ ) with a conspicuos ridge adjacent to the aperture. Exina of two layers, aproximatly 1,5 $\mu \mathrm{m}$ thick. Sexine thicker than nexine; perforategranulate. Infratectal ornamentation microreticulate, lumina size less than $1 \mu \mathrm{m}$. Sexine calymmate ( the sexine is continuous around the tetrad whereas the food layer continues around each monad of the tetrad and absent from the proximal hemisphere and the equatorial region of each pollen grain), about $1 \mu \mathrm{m}$, tectate, tectum thin, bacules short and wide, baculate and foot layers separate at the base of the pore forming a large cubiculum (term proposed in Srivastava \& Braman, 2010); endopore not seen. Nexine less than $0.5 \mu \mathrm{m}$.

Measurements: Equatorial diameter $27 \mu \mathrm{m}(2$ specimens).

Studied material: 3121B: H32/1(Cerro Malvinera locality). 4045a: F50/3 (La Barca
Formation).

Localities: Cerro Malvinera and La Barca.

Other records in Argentina.

Gamerro \& Barreda (2008) compared there material with Rosannia manika Srivastava from Pedro Luro Formation (Maastrichtian?-Danian) of central Argentina (Ruiz \& Quattrocchio, 1997) but they said that it was impossible to achieve an accurate comparison because there are not description. A description of the material from Pedro Luro Formation is given in this paper as Rosannia cf. manika (Srivastava) Srivastava \& Braman 2010.

\section{Rosannia cf. manika (Srivastava) Srivastava \& Braman 2010 \\ (Fig. 4 E-F)}

Description: Pollen grains shed in permanent tetrads, radiosymmetric. Individual grains monoporate, ana-ulcerate, slightly constricted proximally but distally flared; pore large situated at the distal end of an individual grain (diameter: $8-10 \mu \mathrm{m})$. Exine of two layers, $1 \mu \mathrm{m}$ thick. Sexine thicker than nexine; perforate- scabrate. Sexine calymmate (the sexine is continuous around the tetrad whereas the food layer continues around each monad of the tetrad and absent from the proximal hemisphere and the equatorial region of each pollen grain). Nexine very thin, dificult to distinguish except in the equatorial region of each grain.

Measurements: Equatorial diameter 28-37 $\mu \mathrm{m}$ (9 specimens).

Studied material: 2972/4: E 31/4: $37 \mu \mathrm{m}$. 2972/7: K 41/4 :34 $\mu \mathrm{m}$.

Type locality: Puerto Belgrano № 20 borehole (813,8-813,9 m depth). Colorado Basin (Argentina). Pedro Luro Formation.

Age: On the basis of foraminiferal, dinoflagellates and nannoplankton dating, the age of studied level is Upper Danian (Quattrochio \& Sarjeant, 1996).

Remarks: We compare and not assigned to $R$. manika due to in the present material the infratectal ornamentation microreticulate characteristic of the species is not observed. The sexine is thinner $(1.0 \mu \mathrm{m})$ in the studied material in relation to the type species $(1.5 \mu \mathrm{m})$. This material shows a close resemblance to Lactoris type of Gamerro \& Barreda (2008) and Lactoripollenites africanus Zavada \& Benson (1987), sharing a similar morphology. The distal aperture is clearly defined in one of the specimen of Pedro Luro Formation, characteristic not observed in 


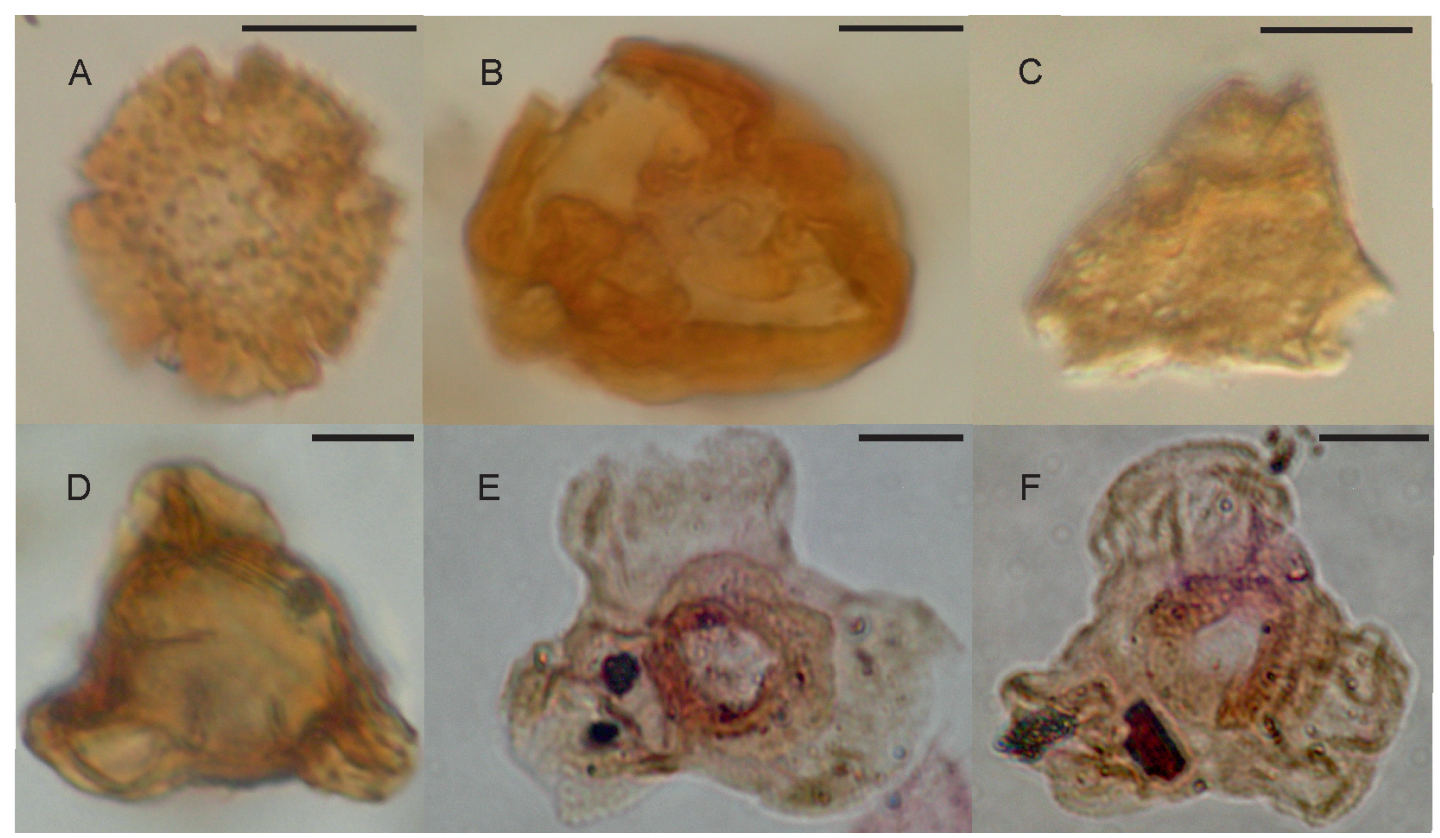

Fig. 4. A. Nothofagidites fortispinulosus: 4045a: S41/2. B. Phyllocladidites mawsonii: 4045a: X39/4. C. Proteacidites sp. : 4045a: L36/2. D. Rosannia manika: 4045a: F50/3. E-F: Rosannia cf. manika: 2972/7: K41/4. 2972/4: E31/4. Scale bars $=10 \mu \mathrm{m}$.

Lactoris type (Gamerro \& Barreda, 2008).

Lactoripollenites from Australia (Macphail et al., 1999) differs in having a thick exine $(1,5-2 \mu \mathrm{m})$ and larger size $(40-56 \mu \mathrm{m})$ than the present material $(28-37 \mu \mathrm{m})$.

\section{DISCUSSION}

The new register of the Lactoridaceae in the area of Cerro Malvinera expanded the known fossil range of this family in Patagonia. To evaluate the age of the succession at Cerro Malvinera its palynology was compared to that of different Paleogene formations (La Barca, Punta Torcida and Puesto José) at its type locality, exposed in the Austral Basin. Several dinocyst events were recognized in the compared Paleogene formations. The first occurrences (FO) and last occurrences (LO) of these events are documented in Table 2. Magnetostratigaphycally calibrated ages of key dinocysts species in the Southern Ocean (Bijl et al., 2013) and from other sections in the world recognized in these formations are given.

In comparing the palynomorphs of Cerro Malvinera with those recorded in La Barca, Punta Torcida and Puesto José formations (Table 3) it should be noted that the majority of taxa of this profile are present in La Barca Formation (7 species in common). Four species are shared with Punta Torcida Formation and only two with Puesto José Formation.

Cerro Malvinera samples and La Barca Formation share the presence of : Rosannia manika Srivastava \& Braman (Lactoridaceae); in the sporomorphs group: Biretisporites crassilabratus, Araucariacites australis, Podocarpidites spp. and Nothofagidites spp. and in the dinoflagellate group: Lingulodinium bergmannii (Paleocene-middle Eocene) and Pentadinium laticinctum (FO 51.95-LO 11.2 ).

With Punta Torcida Formation shared the presence of Araucariacites australis, Podocarpidites spp., Lingulodinium bergmannii and Spiniferites ramosus. And with Puesto José Formation only Biretisporites crassilabratus and Nothofagidites spp.

In Table 3 the list of palynomorphs recognized in the different formations is given. Taking into account the dinocysts species some stratigraphic considerations about the analyzed formations are given.

La Barca Formation is considered to be Late Paleocene in previous studies (Olivero et al., 2002) due to the presence of Paleocystodinium golzowense. According to Bijl et al., 2013 this species has its LO 51. $50 \mathrm{Ma}$ in the South Pacific Ocean and in other oceans FO 54.31 Ma (Table 2). Also this species is present in Austral Basin, 
Table 2: Magnetostratigraphically calibrated ages of key dinocyst species in the Southern Ocean and from other sections in the World ( Bijl et al., 2013, William et al., 1998, 1999, 2003).

\begin{tabular}{|c|c|c|c|c|}
\hline \multirow[t]{2}{*}{ Dinocyst species } & \multicolumn{2}{|c|}{ South Pacific Ocean } & \multicolumn{2}{|c|}{ Other oceans } \\
\hline & FO Error & LO Error & FO Error & LO Error \\
\hline Apectodinium homomorphum & 58.200 .65 & 48.800 .20 & & \\
\hline Batiacasphaera micropapillata & & & 41.0 & 3.0 \\
\hline Cleistosphaeridium diversispinosum & 49.300 .20 & 38.300 .30 & & \\
\hline Deflandrea antarctica & 58.200 .30 & & $? 55$ & \\
\hline Dracodinium waipawaense & 53.400 .10 & 50.000 .40 & 53.400 .10 & 51.300 .10 \\
\hline Hystrichosphaeridium tubiferum & & & 117.48 & 46.00 \\
\hline Membranophoridium perforatum & 51.800 .20 & 45.500 .20 & & \\
\hline Palaeocystodinium golzowense & & 51.500 .20 & 54.31 & 9 \\
\hline Pentadinium laticinctum & & & 51.95 & 11.21 \\
\hline Vozzhennikovia apertura & 65.100 .40 & & Transantarctic flora & \\
\hline
\end{tabular}

Chile in the Chorrillo Chico Formation in the Late Paleocene associated with Palaeoperidinium pyrophorum (Late Campanian-Late Selandian) and in the lower part (early Eocene) of Agua Fresca Formation (Quattrocchio, 2009). The presence of Palaeocystodinium golzowense from PP18 sample upwards in the Agua Fresca Formation (early to middle Eocene) is considered reworking (Quattrocchio, 2009). Other species are Operculodinium azcaratei, Volkheimeridium lantern, which were cited for Chorrillo Chico and Agua Fresca formations, Paleocene- middle Eocene of Chile (Quattrocchio, 2009).

Due to the presence of Pentadinium laticinctum (FO 51.95 Ma- LO 11.21 Ma in other oceans) an age not older than early Eocene is proposed for La Barca Formation in the studied sample of LB2 member.

Punta Torcida Formation includes the quasiglobally recorded of the genus Apectodinium homomorphum (FO $58.20 \mathrm{Ma}$ ) associated with the $\mathrm{P} / \mathrm{E}$ boundary. Cleistosphaeridium diversispinosum (FO 49.30 Ma early Eocene), Achilleodinium latispinosum (early Eocene), Deflandrea fuegiensis, Habibacysta sp. Impagidinium maculatum (Eocene), Lingulodinium bergmannii (Paleocene-Eocene), Oligosphaeridium complex (FO 135.2 Ma-LO 48.5 Ma), Membranophoridium perforatum (FO $51.80 \mathrm{Ma}$ - LO $45.50 \mathrm{Ma}$ ), Operculodinium azcaratei (present in Chorrillo Chico and Agua Fresca Formations, Chile (Paleocene-middle Eocene), Vozzhennikovia apertura (Paleoceno-Oligoceno) are also identified. An age not older than early Eocene is proposed due to the presence of Cleistosphaeridium diversispinosum (FO 49.30 Ma., early Eocene),
Achilleodinium latispinosum (early Eocene) and Impagidinium maculatum (Eocene). The presence of Oligosphaeridium complex suggests an age not younger than early Eocene and Membranophoridium perforatum proposes an age not younger than middle Eocene. The assemblage of Punta Torcida resembles those of Agua Fresca Formation in Punta Prat locality (Quattrocchio, 2009), specially its lower and middle part.

An age not older than middle Oligocene is proposed for the studied samples from Puesto José Formation due the presence of Phthanoperidinium coreoides, which it is associated with Leujenecysta fallax (middle Eocene to middle Miocene).

\section{Migration routes}

The discovery of fossil pollen of Lactoridaceae in the Late Cretaceous (early TuronianCampanian) deposits of the south-west coast (Orange Basin offshore Namaqualand), South Africa suggests that this family may have been a common element in the Cretaceous Gondwana flora (Zavada \& Benson, 1987). Due to the type material was documented from cutting samples; the Turonian age for the Lactoridaceae should be cautiously accepted (Srivastava \& Braman, 2010).

Different explanations have been postulated about the migratory routes of the family now restricted to a volcanic island in the Pacific Ocean (Macphail et al., 1999; Gamerro \& Barreda, 2008; Srivastava \& Braman, 2010). In Australia, pollen grains of one or more closely related species of Lactoripollenites Zavada \& 
Table 3: List of palynomorphs recognized in the analyzed formations.

\begin{tabular}{|c|c|c|c|c|c|c|c|}
\hline \multirow{2}{*}{\begin{tabular}{|l} 
Formations/Locality \\
Samples
\end{tabular}} & \multicolumn{2}{|c|}{ LaBarca } & \multicolumn{2}{|c|}{ PuntaTorcida } & \multicolumn{2}{|c|}{ PuestoJosé } & \multirow[t]{2}{*}{$\begin{array}{c}\text { Co.Malvi- } \\
\text { nera }\end{array}$} \\
\hline & 4045 & 4046 & 4047 & 4048 & 4049 & 4050 & \\
\hline \multicolumn{8}{|l|}{ Spores } \\
\hline Baculatisporites comaumensis & & $x$ & & $\mathrm{x}$ & & & \\
\hline Biretisporites crassilabratus & & $\mathrm{x}$ & & & & $\mathrm{x}$ & $\mathrm{x}$ \\
\hline Cingutriletes australis & $\mathrm{x}$ & $\mathrm{x}$ & & & & & \\
\hline Corrugatisporites argentinus & & & & & $\mathrm{x}$ & & $\mathrm{x}$ \\
\hline Cyathidites paleospora & & $\mathrm{x}$ & & & & & \\
\hline Deltoidospora australis & & $\mathrm{x}$ & & & & & \\
\hline \multicolumn{8}{|l|}{ Gymnosperm pollen } \\
\hline Araucariacites australis & $\mathrm{x}$ & $\mathrm{x}$ & & $\mathrm{x}$ & $x$ & & $x$ \\
\hline Dilwynites granulatus & & & $\mathrm{x}$ & & & & \\
\hline Microcachryidites australis & & $\mathrm{x}$ & & & & & \\
\hline Phyllocladidites mawsonii & $x$ & $\mathrm{x}$ & & & & & \\
\hline Podocarpidites spp. & & & & $\mathrm{x}$ & & & $x$ \\
\hline \multicolumn{8}{|l|}{ Angiosperm pollen } \\
\hline Diporites aspis & $\mathrm{x}$ & $\mathrm{x}$ & & & & & \\
\hline Nothofagidites fortispinulosus & $\mathrm{x}$ & $\mathrm{x}$ & & & & $\mathrm{x}$ & \\
\hline Nothofagidites spp. & & & & & & & $\mathrm{x}$ \\
\hline Proteacidites sp. & $\mathrm{x}$ & $\mathrm{x}$ & & $\mathrm{x}$ & & & \\
\hline Rosannia manika & $\mathrm{x}$ & & & & & & $x$ \\
\hline \multicolumn{8}{|l|}{ Dinoflagellates } \\
\hline Achilleodinium latispinosum & & & $x$ & $\mathrm{x}$ & & & \\
\hline cf. Adnatosphaeridium sp. A & & & $\mathrm{x}$ & & & & \\
\hline Apectodinium homomorphum & & & & $\mathrm{x}$ & & & \\
\hline Batiacasphaera rifensis & & $x$ & & & & & \\
\hline Batiacasphaera micropapillata & $\mathrm{x}$ & $\mathrm{x}$ & & & & & \\
\hline Cleistosphaeridium diversispinosum & & & $x$ & $x$ & & & \\
\hline Deflandrea fuegiensis & & & $\mathrm{x}$ & $x$ & & & \\
\hline Dracodinium waipawaense & & & $\mathrm{x}$ & & & & \\
\hline Habibacysta sp. & & & & $\mathrm{x}$ & & & \\
\hline Hystrichosphaeridium tubiferum & & & $\mathrm{x}$ & & & & \\
\hline Impagidinium maculatum & & & & $\mathrm{x}$ & & & \\
\hline Isabelidinium bakeri & & $x$ & & & & & \\
\hline Lejeunecysta fallax & $x$ & & & & & & \\
\hline Lejeunecysta cf. pulcra & & & $\mathrm{x}$ & & & & \\
\hline Lingulodinium bergmannii & $\mathrm{x}$ & $\mathrm{x}$ & & $\mathrm{x}$ & & & $\mathrm{x}$ \\
\hline Magallanesium sp. & & $\mathrm{x}$ & & & & & \\
\hline Membranisphoridium perforatum & & & $\mathrm{x}$ & $\mathrm{x}$ & & & \\
\hline Oligosphaeridium complex & & & $\mathrm{x}$ & $\mathrm{x}$ & & & \\
\hline Operculodinium azcaratei & & $\mathrm{x}$ & & $\mathrm{x}$ & & & \\
\hline Palaeocystodinium golzowense & $\mathrm{x}$ & $\mathrm{x}$ & & & & & \\
\hline Pentadinium laticinctum & $x$ & & & & & & $\mathrm{x}$ \\
\hline Phthanoperidinium coreoides & & & & & $\mathrm{x}$ & & \\
\hline Pyxidinopsis waipawaensi & & & & $\mathrm{x}$ & & & \\
\hline Spiniferites ramosus & & & & $\mathrm{x}$ & & & $x$ \\
\hline Volkheimeridium lanterna & & $x$ & & & & & \\
\hline Vozzhennikovia apertura & & & & $\mathrm{x}$ & & & \\
\hline \multicolumn{8}{|l|}{ Acritarchs } \\
\hline Pterospermella $\mathrm{sp}$. & & & & & & & $\mathrm{x}$ \\
\hline
\end{tabular}


Benson, 1987 have been recorded since 1970 in marine and terrestrial sediments, which range in age from Campanian to early Oligocene (Macphail et al., 1999). Macphail et al. (1999) considered that the Lactoridaceae could have entered Australia through the north from Africa during the middle-late Campanian. None of the Southeast Australian specimens of Lactoridace were an exact match for the South African and it could be presume that Lactoris fernandeziana is merley the sole survivor of a much larger clade (Mcphail com.pers.).

Lactoridaceae is also present in in the Danian and early Miocene of South America (Ruiz \& Quattrocchio, 1997; Gamerro \& Barreda, 2008, Barreda et al., 2012) and the Senonian of India (Prasad et al., 1995; Prasad \& Pundeer, 2002), which was connected with Africa in the Senonian (Srivastava, 1988; Briggs, 2003). Africa and South America had land connections by the Río Grande Rise and the Walvis Ridge then the migrations of Lactoridaceae in the late Cretaceous throughout the Atlantic Ocean could be possible (Gamerro \& Barreda, 2008). Gamerro and Barreda (2008) also postulated a migration via Antarctica due to the record of this family (Lactoridaceae s.l. A. Partridge, pers. comm. in Gamerro \& Barreda 2008) in the Maastrichtian (López de Bertodano Formation). The southernmost extreme of South America (Patagonia) remained connected to the present Antarctic Peninsula at least up until about $30 \mathrm{Ma}$., that was part of the landscape up to the first part of the Paleogene, and quite probably also including part of the remaining Antarctic continent (Pascual \& Ortiz-Jaureguizar, 2007) . Secular variation of neodymium isotope ratios at Agulhas Ridge (Southern Ocean, Atlantic sector) suggests an early middle Eocene (approximately $41 \mathrm{Ma}$ ) for the opening of the Drake Passage (Scher \& Martin, 2006)

The migration from North to South America is also possible (Gamerro \& Barreda, 2008). By the beginning of the Late Cretaceous, the volcanic and diastrophic processes that finally led to the differentiation of the Caribbean region and Central America built up transient geographic connections that permitted the initiation of an overland inter-American exchange that included dinosaurian titanosaurs from South America and hadrosaurs from North America. Marsupials (polydolopimorphian marsupials) were assumed to have differentiated in South America prior to new discoveries from the North American Late Cretaceous (Pascual \& Ortiz-Jaureguizar, 2007). But the lack of fossils of Lactoridaceae in north- ern and central South America indicates that this route (North American) could be less probably (Gamerro \& Barrera, 2008).

The route followed by this family to its present distribution is explained in Gamerro \& Barreda (2008, p. 48). The youngest record is in the early Miocene (Austral Basin) in Argentina. Gamerro \& Barreda (2008) considered that Lactoris migrated to the west (Robinson Crusoe Island) before the Andean maximum uplift in the middle-late Miocene.

A migration via Antarctica is postulated in this paper due to the record of this family in the Maastrichtian (Lopez de Bertodano Formation). The southernmost extreme of South America (Patagonia) remained connected to the present Antarctic Peninsula at least up until about 41 Ma. Depending on new records due to the presence of this family in the Colorado Basin in the Danian, a migration route from the north of Patagonia to the south (Austral Basin) it is not discarded.

\section{CONCLUSION}

The majority of palynomorph taxa from the Cerro Malvinera succession are present in the upper member LB2 of the La Barca Formation and both shared the presence of Lactoridaceae (Rosannia manika Srivastava) and the age-diagnostic dinocysts Pentadinium laticinctum (First Occurrences $51.95 \mathrm{Ma}$ ). An age not older than early Eocene is proposed for the studied samples of LB2 member of the La Barca Formation and the Cerro Malvinera strata.

These data expands the known fossil record of the Lactoridaceae in Patagonia and contributes to elucidate the probably migration routes of this family. A migration via Antarctica is postulated in this paper due to the record of this family in the Maastrichtian (Lopez de Bertodano Formation). The southernmost extreme of South America (Patagonia) remained connected to the present Antarctic Peninsula at least up early middle Eocene (approximately $41 \mathrm{Ma}$ ). Depending on new records due to the presence of this family in the Colorado Basin in the Danian, a migration route from the north of Patagonia to the south (Austral Basin) it is not descarded.

\section{ACKNOWLEDGEMENTS}

This work was supported by Secretaría General de Ciencia y Tecnología de la Universidad Nacional del Sur (SEGCyT) under Grant [PGI- 
24/H126.-M.A.Martínez]. Special thanks for Dr. Norberto Malumián and Dr. Eduardo Olivero for the outcrop samples and discussion about the stratigraphy of the studied area.

\section{BIBLIOGRAPHY}

Barreda V.D., N.R. Cúneo, P. Wilf, E.D. Currano, R.A. Scasso \& H. Brinkhuis. 2012. Cretaceous/ Paleogene Floral Turnover in Patagonia: Drop in Diversity, Low Extinction, and a Classopollis Spike. PLoS ONE 7(12): e52455. doi:10.1371/journal.pone. 0052455

Bernardello, G., G.J. Anderson, S.P.Lopez, M.A. Cleland, T.F. Stuessy \& D.J. Crawford. 1999. Reproductive biology of Lactoris fernandeziana (Lactoridaceae). American Journal of Botany 86(6): 829-840.

Bijl, P.K., A. Sluijs \& H. Brinkhuis. 2013. A magnetoand chemostratigraphically calibrated dinoflagellate cyst zonation of the early Palaeogene South Pacific Ocean. Earth-Science Reviews 124: 1-31

Briggs, J.C. 2003. The biogeography and tectonic history of India. Journal of Biogeography 30: 381-388.

Carlquist, S. 1964. Morphology and relationships of Lactoridaceae. Aliso 5: 425-435.

Crawford, D.J., T.F. Stuessy, M.B. Cosner, D. Haines, D. Wiens \& P. Peñalillo. 1994. Lactoris fernandeziana (Lactoridaceae) on the Juan Fernandez Islands: allozyme uniformity and field observations. Conservation Biology 8: 277-280.

Crawford, D.J., T.F. Stuessy , D. Wiens \& D.W. Haines. 1991. The Lactoridaceae on the Juan Fernandez Islands: enzyme electrophoresis and new observations on number and sizes of populations. American Journal of Botany : 176 (Abstract).

Chase, M. W., \& 41 others. 1993. Phylogenetics of seed plants: an analysis of nucleotide sequences from the plastid green rbcL. Annals of the Missouri Botanical Garden 80: 528-580.

Donoghue, M.J.\& J.A. Doyle. 1989. Phylogenetic analysis of angiosperms and the relationships of Hamamelidae. In P. R. Crane and S. Blackmore [eds.], Evolution, systematics and fossil history of the Hamamelidae, pp. 17-45. Clarendon Press, Oxford.

Endress, R K., 1994. Floral structure and evolution of primitive angiosperms: recent advances. Plant Systematics and Evolution 192: 79-97.

Gamerro, J.C. \& V. Barreda. 2008. New fossil record of Lactoridaceae in southern South America: a palaeobiogeographical approach. Botanical Journal of the Linnean Society 158: 41-50.

Ghiglione, M.C., Ramos, V.A. \& E.O. Cristallini. 2002. Estructura y estratos de crecimiento en la faja plegada y corrida de los Andes Fueguinos. Revista Geológica de Chile 29: 17-41.

Hollis, C.J. 1997. Cretaceous-Paleocene Radiolaria from eastern Marlborough, New Zealand. Institute of Geological and Nuclear Sciences monograph 17. New Zealand Geological Survey, Paleontological Bulletin 73: 152 .
Jannou, G.E. 2009. Microfósiles marinos del Eoceno inferior, Isla Grande de Tierra del Fuego, Argentina: Bioestratigrafía, Paleoambiente y Paleo-biogeografía. Ph.D. Thesis (Inedit.), Facultad de Ciencias Exactas y Naturales, Universidad de Buenos Aires: 228 pp.

Jannou, G.E. 2014. Aspectos bioestratigráficos, paleoambientales y paleoclimáticos de los radiolarios de la Formación Punta Torcida, Eoceno Inferior, Cuenca Austral, Sur de Sudamérica. XIX Congreso Geológico Argentino, Junio 2014, Córdoba. T2-2.

Jannou, G. \& E.B.Olivero. 2001. Hallazgo de radiolarios del Paleógeno en la Isla Grande de Tierra del Fuego, Argentina. Ameghiniana 38: 317-320.

Klepeis, K.A. \& J.A. Austin Jr. 1997. Contrasting styles of superposed deformation in the southernmost Andes. Tectonics 16: 755-776.

Macphail M.K, A.D Partridge \& E.M Truswell. 1999. Fossil pollen records of the problematical primitive angiosperm family Lactoridaceae in Australia. Plant Systematics and Evolution 214: 199-210.

Malumián, N. \& A. Caramés. 2002. Foraminíferos de la Formación La Barca, Paleoceno superior, Tierra del Fuego Argentina. Revista de la Asociación Geológica Argentina 57: 219-231.

Malumián, N. \& E.B. Olivero. 2006. El Grupo Cabo Domingo, Tierra del Fuego: Bioestratigrafía, paleoambientes y acontecimientos del EocenoMioceno marino. Revista de la Asociación Geológica Argentina 61(2): 139-160.

Malumián, N., C. Náñez, M.S. Alonso \& A. Baleirón. 2008. Pozo Poseidón 1: El Paleógeno de la plataforma continental, Isla Grande de Tierra del Fuego. In: Congreso Geológico Argentino, No. 17. Resúmenes: 859-860. Jujuy.

Olivero, E.B. \& M.I. López Cabrera. 2001. Ichnology of syntectonic turbidites, estuarine and shelf deposits. Eocene, Punta Torcida anticline, Isla Grande de Tierra del Fuego. 4 Reunión Argentina de Icnología y 2 Reunión de Icnología del Mercosur, S.M. Tucumán, Resúmenes, 62.

Olivero, E.B. \& N. Malumián. 1999. Eocene stratigraphy of Southern Tierra del Fuego. American Association of Petroleum Geologists Bulletin 83: 295-313.

Olivero, E.B. \& N. Malumián. 2008. Mesozoic-Cenozoic stratigraphy of the Fuegian Andes, Argentina. Geologica Acta 6 (1): 5-18.

Olivero, E.B., N. Malumián, S. Palamarczuk \& R.A. Scasso. 2002. El Cretácico Superior-Paleógeno del área del Río Bueno, costa atlántica de la Isla Grande de Tierra del Fuego. Revista de la Asociación Geológica Argentina 57: 199-218

Olivero, E.B., J.J Ponce, M.I. López Cabrera \& D.R. Martinioni. 2004. Phymatoderma granulata from the Oligocene-Miocene of Tierra del Fuego: morphology and ethology. First International Congress on Ichnology, Ichnia 2004, Abstract Book: 63. Trelew.

Torres Carbonell, P.J., N. Malumián \& E.B. Olivero. 2009. El Paleoceno-Mioceno de Península Mitre: antefosa y depocentro de techo de cuña de la cuen- 
ca Austral, Tierra del Fuego, Argentina. Andean Geology 36 (2): 197-235.

Pascual, R. \& E. Ortiz-Jaureguizar. 2007. The Gondwanan and South American Episodes: Two Major and Unrelated Moments in the History of the South American Mammals. Journal of Mammal Evoutionl 14:75-137 DOI 10.1007/s10914-0079039-5.

Prasad, B. \& B.S. Pundeer. 2002. Palynological events and zone in Cretaceous-Tertiary boundary sediments of Krishna-Godavari and Cauvery basins, India. Palaeontographica, Abt. B 262 (1-4): 39-70.

Prasad, B., A.K. Jain \& Y.K. Mathur. 1995. A standard palynozonation scheme for the Cretaceous and Pre-Cretaceous subsurface sediments of KrishnaGodavari Basin, India. Geoscience Journal 10: $155-220$.

Quattrocchio, M.E. Dinoflagellate from the Paleogene of Punta Prat (Chile). 2009. Palynology 33(1): 141156.

Ruiz, L.C. \& M.E. Quattrocchio. 1997. Estudio palinológico de la Formación Pedro Luro (Maastrichtiano?Paleoceno) en la Cuenca del Colorado, República Argentina. Parte 2: Turma Saccites, Plicates, Poroses e Incertae Sedis. Revista Española de Micropaleontología 29: 115-137.

Srivastava, S.K. 1968. Rosannia manika gen. et sp. nov. from the Edmonton Formation (Maastrichtian), Alberta, Canada. Canadian Journal of Botany 46: 949-951.

Srivastava, S.K. 1988. Ctenolophon and Sclerosperma paleogeography and Senonian Indian plate position. Journal of Palynology 23-24 (1987-1988): 239253.

Srivastava, S.K. \& D.R. Braman, 2010. The revised generic diagnosis, specific description and synonymy of the Late Cretaceous Rosannia manika from Alberta, Canada: its phytogeography and affinity with family Lactoridaceae. Review of Palaeobotany and Palynology 159:2-13. DOI:10.1016/j. revpalbo.2009.10.003.

Stuessy, T.F., D.J. Crawford, G.J. Anderson \& R.J. Jenner. 1998. Systematics, biogeography and conservation of Lactoridaceae. Perspectives in Plant
Ecology, Evolution, and Systematics 1/2: 267-290.

Stuessy, T. F., U. Swenson, D. J. Crawford, G. J. Anderson \& M. Silva. 1997. Plant conservation in the Juan Fernandez Islands. Aliso 16: 89-102.

Torres Carbonell, P.J., Olivero, E.B. \& L.V. Dimieri. 2008. Structure and evolution of the Fuegian Andes foreland thrust-fold belt, Tierra del Fuego, Argentina: paleogeographic implications. Journal of South American Earth Sciences 25: 417-439.

Torres Carbonell, P. J., N. Malumián \& E.B. Olivero. 2009. El Paleoceno-Mioceno de Península Mitre: antefosa y depocentro de techo de cuña de la cuenca Austral, Tierra del Fuego, Argentina. Andean Geology, 36, 197-235.

Vandenberghe, N., R.P. Speijer \& F.J. Hilgen. 2012. The Paleogene period. In: Gradstein, F.M., Ogg, J.G., Schmitz, M., Ogg, G. (Eds.), The Geologic Time Scale 2012. Elsevier, Amsterdam, pp. 855-922.

Volkheimer, W. \& D. Melendi. 1976. Palinomorfos como fósiles guías (3ra. Parte). Técnicas de laboratorio palinológico. Revista Minera, Geología y Mineralogía. Sociedad Argentina de Minería y Geología 34: 19-30.

Williams, G.L., J.P. Bujak \& H. Brinkhuis. 1999. Mesozoic-Cenozoic dinoflagellate cyst course. Urbino, Italy. May 17-22, 1999. Unpubl. data.

Williams, G.L., H. Brinkhuis, J.P. Bujak, S.P. Damasa, P.A. Hochuli, L. de Verteuil \& D. Zevenboom. 1998. Dinoflagellate cysts. In: "Appendix to J. Hardenbol, J. Thierry, M.B. Farley, T. Jacquin, P.C. de Graciansky \& P.R. Vail. Mesozoic and Cenozoic sequence chronostratigraphic framework of European Basins. Society of Sedimentologists and Geologists, Special Publication 60: 764-765.

Williams, G.L., H. Brinkhuis, M.A. Pearce, Fensome, R.A. \& J.W.Weegink. 2004. Southern Ocean and global dinoflagellate cyst events compared: Index events for the late Cretaceous-Neogene. In: N. Exon \& J.P. Kennett (eds.), Proceedings of the Ocean Drilling Program, Scientific Results 189: 1-98.

Zavada MS, J. M. \& J. Benson. 1987. First fossil evidence for the primitive angiosperm family Lactoridaceae. American Journal of Botany 74: 1590-1594.

Doi: 10.22179/REVMACN.19.496 